\title{
Hepatotoxicity and oxidative stress induced by Naja haje crude venom
}

\author{
Saleh Al-Quraishy ${ }^{1 \dagger}$, Mahamed A Dkhil ${ }^{1,2 \dagger}$ and Ahmed Esmat Abdel Moneim ${ }^{2,3^{*}+}$
}

\begin{abstract}
Background: Snake venoms are synthesized and stored in venom glands. Most venoms are complex mixtures of several proteins, peptides, enzymes, toxins and non-protein components. In the present study, we investigated the oxidative stress and apoptosis in rat liver cells provoked by Naja haje crude injection $\left(\mathrm{LD}_{50}\right)$ after four hours.

Methods: Wistar rats were randomly divided into two groups, the control group was intraperitoneally injected with saline solution while $\mathrm{LD}_{50}$-dose envenomed group was intraperitoneally injected with venom at a dose of $0.025 \mu \mathrm{g} / \mathrm{kg}$ of body weight. Animals were killed four hours after the injection. Lipid peroxidation, nitric oxide and glutathione levels were measured as oxidative markers in serum and liver homogenate. In addition, liver function parameters and activities of antioxidant enzymes were determined.
\end{abstract}

Results: $N$. haje crude venom $(0.025 \mu \mathrm{g} / \mathrm{kg}$ of body weight) enhanced lipid peroxidation and nitric oxide production in both serum and liver with concomitant reduction in glutathione, catalase, glutathione reductase and glutathione-Stransferase activities. Superoxide dismutase and glutathione peroxidase activities were significantly increased in liver of envenomed rats. These findings were associated with apoptosis induction in the liver. In addition, $N$. haje crude venom caused hepatic injury as indicated by histopathological changes in the liver tissue with an elevation in total bilirubin, serum alanine aminotransferase, aspartate aminotransferase, y-glutamyl transpeptidase, and alkaline phosphatase.

Conclusions: Based on the present results, it can hypothesized that N. haje crude venom is a potent inducer of toxin-mediated hepatotoxicity associated with apoptosis in the liver.

Keywords: Naja haje venom, Hepatotoxicity, Oxidative stress, Apoptosis, Rats

\section{Background}

Snake venoms comprise complex mixtures that contain numerous different biological active compounds such as proteins, peptides and nucleotides. A number of these proteins interact with components of the human hemostatic system producing diverse effects [1].

The Elapidae family of venomous snakes - found in tropical and subtropical regions around the world - includes cobras, mambas, sea snakes and coral snakes [2]. Several species of cobras are natives to Africa, among them is the Egyptian cobra Naja haje (Linnaeus) found from southern Egypt to northern South Africa [3]. The

\footnotetext{
* Correspondence: aest1977@hotmail.com

${ }^{\dagger}$ Equal contributors

${ }^{2}$ Department of Zoology and Entomology, Faculty of Science, Helwan University, Cairo, Egypt

${ }^{3}$ Department of Biochemistry and Molecular Biology, Asturias Institute of Biotechnology, University of Oviedo, 33006 Oviedo, Spain

Full list of author information is available at the end of the article
}

venom of the Egyptian cobra consists mainly of neurotoxins and cytotoxins [4].

The venom of Egyptian cobra affects the nervous system by blocking the transmission of nerve signals to muscles and at later stages stopping those transmitted to the heart and lungs as well, causing death due to complete respiratory failure. Envenomation causes local pain, severe swelling, blistering, necrosis and variable non-specific effects [4]. Progress made over the past several decades has given rise to the identification of many of the venom components primarily responsible for these effects including phospholipases $\mathrm{A}_{2}$ and metalloproteinases. The former induces local myonecrosis and lymphatic vessel damage, whereas snake venom metalloproteinases (SVMPs) are responsible for local hemorrhage, extracellular matrix degradation, blistering and skin necrosis [5-7]. In addition, both $\mathrm{PLA}_{2} \mathrm{~S}$ and SVMPs promote an inflammatory response that sets the stage for tissue repair and

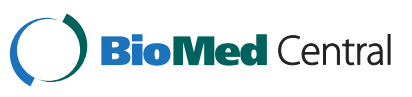

(c) 2014 Al-Quraishy et al.; licensee BioMed Central Ltd. This is an Open Access article distributed under the terms of the Creative Commons Attribution License (http://creativecommons.org/licenses/by/4.0), which permits unrestricted use, distribution, and reproduction in any medium, provided the original work is properly credited. The Creative Commons Public Domain Dedication waiver (http://creativecommons.org/publicdomain/zero/1.0/) applies to the data made available in this article, unless otherwise stated. 
regeneration but, at the same time, may contribute to further tissue damage $[8,9]$. Insights into the molecular structure of locally acting toxins has led to understanding their structure-function relationships and of the mechanisms involved in myonecrosis, hemorrhage, lymphatic vessel damage and dermonecrosis [5-7,10-12].

Reactive oxygen species are involved in the inflammatory responses, thereby affecting the cellular physiology and playing a significant role in the pathological conditions [13]. The free radicals, apart from being involved in damaging cellular components, do play a significant role in venom induced toxicity [14].

Nevertheless, the effect of the venom of $N$. haje was not sufficiently covered in the available literature. Thus, it is of interest to examine the possible damaging effect of $\mathrm{LD}_{50}$ of the crude venom on liver of rats, unveiling the molecular mechanisms of venom-induced hepatotoxicity.

\section{Methods}

\section{Experimental animals}

Adult male Wistar albino rats weighing 180-200 g were obtained from The Holding Company for Biological Products and Vaccines (VACSERA, Egypt). Animals were kept in wire-bottom cages in a room under standard condition of illumination with a 12-hours light-dark cycle at $25 \pm 1^{\circ} \mathrm{C}$. They were provided with water and balanced diet ad libitum. We have followed the European Community Directive (86/609/EEC) and national rules on animal care that are in accordance with the NIH Guide for the Care and Use of Laboratory Animals (available at http:// grants.nih.gov/grants/olaw/Guide-for-the-care-and-use-oflaboratory-animals.pdf).

\section{Venom source and chemicals}

Ten specimens of $N$. haje were collected from the western Nile delta in Egypt, in September. They were kept alive in the laboratory at the University of Helwan in individual terrariums, fed fortnightly with mice and offered water ad libitum. Once a month, the snake venom was collected by milking. Then, it was diluted in deionized water, centrifuged at $10,000 \times g$ for 15 minutes and pellets were discarded. The sample was vacuum dried and stored at $-20^{\circ} \mathrm{C}$. Before use, the venom was reconstituted in saline solution, centrifuged at 3,000 rpm for ten minutes at $4^{\circ} \mathrm{C}$ and the supernatant was used in the present study. All solvents and chemicals used in this study were of analytical grade and deionized water was employed as well.

\section{Experimental protocol}

$\mathrm{LD}_{50}$ of $N$. haje crude venom was determined as described by Meier and Theakston [15]. To study the effect $\mathrm{LD}_{50}$ of the crude venom on liver of rats after four hours, 12 adult male albino rats were randomly divided into two groups with six. The first group served as control and received intraperitoneally (IP) an injection of saline solution $(0.2 \mathrm{~mL}$ saline/rat). The second group was injected IP with $\mathrm{LD}_{50}$ of $N$. haje venom in saline solution $(25 \mu \mathrm{g} / \mathrm{kg})$. Animals of the two groups were killed by cervical dislocation, and blood samples were collected by cardiac puncture. Blood was allowed to stand for half an hour and then was centrifuged at $500 \mathrm{~g}$ for 15 minutes at $4^{\circ} \mathrm{C}$ in order to separate serum and stored at $-20^{\circ} \mathrm{C}$ until analysis. Pieces of the liver were weighed and homogenized immediately to give $50 \%(\mathrm{w} / \mathrm{v})$ homogenate in ice-cold medium containing $50 \mathrm{mM}$ Tris- $\mathrm{HCl}, \mathrm{pH}$, 7.4. The homogenate was centrifuged at $500 \mathrm{~g}$ for ten minutes at $4{ }^{\circ} \mathrm{C}$. The supernatant $(10 \%)$ was used for the various biochemical determinations.

\section{Biochemical estimations}

\section{- Liver function test}

Colorimetric determination of alanine aminotransferase (ALT) or aspartate aminotransferase (AST) was estimated by measuring the amount of pyruvate or oxaloacetate produced by forming 2 , 4-dinitrophenylhydrazine according to the method of Reitman and Frankel [16]. Moreover, serum $\gamma$-glutamyl transpeptidase $(\gamma \mathrm{GT})$ and alkaline phosphatase (ALP) were tested using kits purchased from Biodiagnostic Co. (Egypt) according to the method described by Szasz [17] and Belfield and Goldberg [18], respectively. Also, serum total bilirubin (TB) was assayed according to Schmidt and Eisenburg [19].

- Determination of lipid peroxidation and nitric oxide Lipid peroxidation (LPO) and nitrite/nitrate, as an indirect measure of nitric oxide (NO) production, were assayed colorimetrically in serum and liver homogenate according to the method of Ohkawa et al. [20] and Green et al. [21], respectively. LPO was determined by using $1 \mathrm{~mL}$ of trichloroacetic acid $10 \%$ and $1 \mathrm{~mL}$ of thiobarbituric acid $0.67 \%$ and were then heated in a boiling water bath for 30 minutes. Thiobarbituric acid reactive substances were determined by the absorbance at $535 \mathrm{~nm}$ and expressed as malondialdehyde (MDA) formed. Nitric oxide was determined in acid medium and in the presence of nitrite the formed nitrous acid diazotized sulfanilamide is coupled with $\mathrm{N}$-(1-naphthyl) ethylenediamine. The resulting azo dye has a bright reddish-purple color that can be measured at $540 \mathrm{~nm}$.

- Estimation of glutathione and anti-oxidant enzymes Glutathione (GSH) level was determined in serum and liver homogenate by the method of Ellman [22], which is based on the reduction of Ellman's reagent [5,5' dithiobis (2-nitrobenzoic acid) DTNB] with 
GSH in order to produce a yellow compound. The reduced chromogen was directly proportional to GSH concentration and its absorbance was measured at $405 \mathrm{~nm}$. In addition, hepatic catalase (CAT) was determined colorimetrically according to the method of Aebi [23]. The assay is based on catalase-catalyzed reaction of a known quantity of $\mathrm{H}_{2} \mathrm{O}_{2}$ with 3,5-dichloro-2-hydroxybenzene sulfonic acid (DHBS) and 4-aminophenazone (AAP) to form a chromophore, which has a color intensity inversely proportional to the amount of catalase in the original sample which can be measured at $510 \mathrm{~nm}$. Superoxide dismutase (SOD) activity was assayed by the method of Nishikimi et al. [24]. This assay relies on the ability of the enzyme to inhibit the phenazine methosulphate-mediated reduction of nitroblue tetrazolium dye. Also, activities of glutathione-Stransferase (GST), glutathione peroxidase (GPx) and glutathione reductase (GR) were determined by the methods of Habig et al. [25], Paglia and Valentine [26] and Factor et al. [27], respectively.

\section{RT-PCR analysis}

Total RNA was extracted from frozen liver samples of six rats following the Trizol reagent method [28]. The extracted RNA was dissolved in water (diethylpyrocarbonate-treated) and stored at $-70^{\circ} \mathrm{C}$. Five $\mu \mathrm{g}$ of RNA was used as template for cDNA production through incubation with RevertAid ${ }^{\mathrm{ix}} \mathrm{H}$ Minus Reverse Transcriptase Thermo Fisher Scientific Inc, Canada) for one hour at $45^{\circ} \mathrm{C}$, in $10 \mathrm{lM}$ random hexamers, $0.375 \mathrm{mM}$ per dNTP, $3 \mathrm{mM}$ $\mathrm{MgCl}_{2}, 75 \mathrm{mM} \mathrm{KCl}, 50 \mathrm{mM}$ Tris- $\mathrm{HCl}, \mathrm{pH} 8.3,10 \mathrm{mM}$ dithiothreitol, and 40 units RNase inhibitor, followed by five minutes at $70^{\circ} \mathrm{C}$ to inactivate the enzyme. Samples were incubated for 30 minutes at $37^{\circ} \mathrm{C}$ with $0.1 \mathrm{mg} / \mathrm{mL}$ RNAse. PCR amplification was performed in the presence of $2 \mathrm{mM}$ of $\mathrm{MgCl}_{2}, 0.5 \mathrm{mM}$ of each primer (Metabion International, Martinsried, Deutschland), $0.2 \mathrm{mM}$ dNTPs, $2 \mathrm{U}$ of Taq DNA polymerase (GoTaq ${ }^{\mathrm{Tm}}$ DNA Polymerase, Promega Corporation) in a final volume of $25 \mu \mathrm{L}$. Simultaneous amplification of the invariant housekeeping gene GAPDH was performed. The sequences of the primers were as follows:

- iNOS (S): 5'-GAAAGAACTCGGGCATACCT-3'.

- iNOS (AS): 5'-GGCGAAGAACAATCCACAAC-3'.

- GAPDH (S): 5'-CAAGGTCATCCATGACAACTT TG-3'.

- GAPDH (AS): 5'-GTCCACCACCCTGTTGCTGT AG-3'

PCR conditions for iNOS consisted of 35 cycles of denaturation at $95^{\circ} \mathrm{C}$ for $45 \mathrm{~s}$, annealing at $63^{\circ} \mathrm{C}$ for $45 \mathrm{~s}$, and extension at $72^{\circ} \mathrm{C}$ for $45 \mathrm{~s}$. PCR conditions for
GAPDH were 25 cycles of denaturation at $95^{\circ} \mathrm{C}$ for $45 \mathrm{~s}$, annealing at $60^{\circ} \mathrm{C}$ for $45 \mathrm{~s}$, and extension at $72^{\circ} \mathrm{C}$ for $45 \mathrm{~s}$. Following the last cycle, the final extension was performed at $72^{\circ} \mathrm{C}$ for ten minutes for all PCR analyses. PCR products were visualized on a $2 \%$ agarose gel with ethidium bromide staining. The expression of the tested enzyme was normalized to the expression of GAPDH of each sample and compared using TotalLab software.

\section{Flow cytometry}

Liver tissue samples were prepared by manual disaggregation procedure. Briefly, a few drops of RPMI medium were added to tissue and then mixed until complete tissue disaggregation was achieved. Suspended cells were filtered using a $50-\mu \mathrm{m}$ pore size mesh and then centrifuged at $1000 \mathrm{~g}$ for ten minutes. Cells were resuspended in PBS, counted and washed by calcium buffer then centrifuged at $1500 \mathrm{~g}$ for five minutes. The pellet was resuspended and then cells were counted. Annexin-PI apoptotic assay was carried out using BD Annexin V FITC Assay Kit (BD Biosciences, USA). FAC scan Becton-Dickinson (BD) flow-cytometer was used and data were analyzed using cell Quest software.

\section{Western blotting analysis}

Western blotting analysis was performed according to the standard method. Briefly, cell lysates were prepared, separated on $12 \%$ sodium dodecyl sulfate polyacrylamide gels and transferred onto nitrocellulose membrane (Amersham Biosciences, USA). Non-specific reactivity was blocked by incubating the membranes for two hours in 5\% bovine serum albumin at room temperature. Membranes were incubated with primary antibody (SOD, GPx, GR Bax, Bcl-2 or mitochondrial respiratory complexes namely, complex I, II, III and V) overnight at $4^{\circ} \mathrm{C}$. After three washes for ten minutes with phosphate buffered saline tween-20 (PBST), the membranes were incubated at $37^{\circ} \mathrm{C}$ for one hour with the appropriate secondary antibody (1:5000 dilution) and washed three times with PBST. Reactive proteins were detected with the enhanced chemiluminescence (ECL) detection system (Pierce), $\beta$-actin was used as an internal control.

\section{Histopathological examination}

Conventional techniques of paraffin-wax sectioning and hematoxylin-eosin staining were used for histological studies [29]. Pieces of fresh liver tissues were cut and fixed in neutral buffered formalin for 24 hours. Following fixation, livers were washed and processed through an ascending series of ethanol, cleared in methyl salicylate and infiltrated with wax at $57^{\circ} \mathrm{C}$ then embedded in paraffin. Sections of $5 \mu \mathrm{m}$ were cut and stained with aqueous hematoxylin and alcoholic-eosin, then examined in a Olympus microscope at a magnification of $400 \times$. 


\section{Caspase- 3 detection by immunochemistry}

Immunolocalization technique for caspase-3 was performed on 3- to 4- $\mu \mathrm{m}$ thickness sections according to Pedrycz and Czerny [30]. For negative controls, the primary antibody was omitted. In brief, mouse anti-caspase-3 (diluted 1:250, Santa Cruz Biotechnology, USA), was incubated with sections for 60 minutes. Primary antibodies were diluted in Tris buffered saline (TBS)/1\% bovine serum albumin (BSA). Then a biotinylated secondary antibody directed against mice immunoglobulin (Biotinylated Link Universal - DakoCytomation kit, supplied ready to use) was added and incubated for 15 minutes, followed by addition of horse radish peroxidase conjugated with streptavidin (DakoCytomation kit, supplied ready to use) also incubated for 15 minutes. At the sites of immunolocalization of the primary antibodies, a reddish to brown color appeared after adding 3-amino-9-ethylcarbasole (AEC) (DakoCytomationkit, supplied ready to use) for $15 \mathrm{mi}$ nutes. Specimens were counterstained with hematoxylin for one minute and mounted using the Aquatex fluid (Merck KGaA, Germany).

\section{Statistical analysis}

The obtained data were presented as means \pm standard error. Statistical analysis was performed using an unpaired Student's t-test using a statistical package program (SPSS version 17.0). Differences among groups were considered significant at $p<0.05$.

\section{Ethics committee approval}

The present study followed the European Community Directive (86/609/EEC) and national rules on animal care that are in accordance with the NIH Guide for the Care and Use of Laboratory Animals (available at http:// grants.nih.gov/grants/olaw/Guide-for-the-care-and-use-oflaboratory-animals.pdf).

\section{Results}

Changes in levels of serum parameters affected by the single IP injection of crude venom of $N$. haje after four hours are shown in Table 1. Levels of AST, $\gamma$ GT and total billirubin were significantly increased $(p<0.05)$ when compared to untreated rats. However, the level of ALT was non-significantly changed. In addition, the total serum protein level was significantly increased $(38.6 \%$ at $p<0.05$ ) four hours after $N$. haje venom injection.

To check the oxidative stress status in liver in response to $N$. haje crude venom, we measured LPO levels in serum and liver homogenate. Results are displayed in Table 2 and showed that crude venom induced increment in LPO production and NO generation in both serum and liver homogenate. In addition, NO generation in serum and liver increased significantly by $42.97 \%$ and $49.23 \%$, respectively, when compared to control rats
Table 1 Changes in liver function of rats induced by Naja haje venom after four hours

\begin{tabular}{lcc}
\hline Parameters & Control rats & Intoxicated rats \\
\hline Serum ALT $(\mathrm{U} / \mathrm{mL})$ & $70.13 \pm 2.17$ & $75.26 \pm 1.07$ \\
Serum AST $(\mathrm{U} / \mathrm{mL})$ & $56.08 \pm 0.74$ & $95.50 \pm 0.32^{*}$ \\
Serum YGT $(\mathrm{U} / \mathrm{L})$ & $3.88 \pm 0.65$ & $4.32 \pm 0.32^{*}$ \\
Serum ALP $(\mathrm{IU} / \mathrm{L})$ & $55.40 \pm 5.94$ & $147.73 \pm 8.97^{*}$ \\
Serum TB $(\mathrm{mg} / \mathrm{dL})$ & $0.64 \pm 0.21$ & $1.94 \pm 0.53^{*}$ \\
Serum protein $(\mathrm{mg} / \mathrm{dL})$ & $7.20 \pm 0.26$ & $9.98 \pm 0.40^{*}$ \\
\hline
\end{tabular}

*significant changes at $p<0.05$ with respect to the control group; values are means $\pm S E(n=6)$.

ALT: alanine aminotransferase, AST: aspartate aminotransferase, $\gamma \mathrm{GT}: \gamma$ glutamyl transpeptidase, ALP: alkaline phosphatase, TB: total bilirubin.

(Table 2). Through RT-PCR analysis (Figure 1) an increase in iNOS expression was evident only in the envenomated group. iNOS transcription, however, was confirmed to accompany the previously observed increase in NO content in the envenomated group. iNOS transcription, however, was confirmed to accompany the previously observed increase in $\mathrm{NO}$ content in the envenomated group.

In order to investigate the responses of the reactive oxygen scavenging system of liver tissue after four hours of exposure to $N$. haje venom, the level and the activity of enzymatic/non-enzymatic antioxidant system were measured (Table 3). The levels of GSH in serum and liver homogenate were significantly decreased $(p<0.05)$ by $35.26 \%$ and $38.66 \%$, respectively. Moreover, activities of enzymatic antioxidant system were significantly diminished $(p<0.05)$ in the liver, where the activity of GR dropped by $40.72 \%$. Additionally, GST diminished by $60.66 \%$ and CAT activity was decreased by $68.29 \%$ regarding control animals. On the other hand, the SOD and GPx activities were found to be significantly increased $(p<0.05)$ in liver tissue. SOD augmented from $1.06 \pm 0.03$ in control (untreated rats) to $1.72 \pm 0.08 \mathrm{U} / \mathrm{g}$ of tissue in treated rats with $N$. haje crude venom (Table 3).

SOD, GPx, and GR expression in tested tissue was modulated by $N$. haje crude venom. As observed by densitometry, the reduction of GR in envenomated rats was $38 \%$ in comparison with controls (Figure 2). SOD

Table 2 Levels of serum and liver lipid peroxidation (LPO) and nitrite/nitrate (NO) of rats induced by Naja haje snake venom after four hours

\begin{tabular}{lcc}
\hline Parameters & Control rats & Intoxicated rats \\
\hline Serum LPO $(\mathrm{nmol} / \mathrm{mL})$ & $32.37 \pm 1.50$ & $43.55 \pm 1.05^{*}$ \\
Liver LPO $(\mathrm{nmol} / \mathrm{g}$ tissue) & $1027.20 \pm 27.07$ & $1220.34 \pm 40.09^{*}$ \\
Serum NO $(\mu \mathrm{mol} / \mathrm{L})$ & $47.33 \pm 4.03$ & $67.67 \pm 3.60^{*}$ \\
Liver NO $(\mu \mathrm{mol} / \mathrm{g}$ tissue) & $128.54 \pm 5.86$ & $191.82 \pm 15.49^{*}$
\end{tabular}

*significant change at $p<0.05$ with respect to the control group; values are means $\pm S E(n=6)$. 


\section{iNOS}

\section{GAPDH}

\section{Control Venom}

Figure 1 Change in the expressions of inducible nitric oxide synthase (iNOS) in the liver of male rats injected with Naja haje crude venom. The expression of the tested enzyme was normalized by comparison with the expression of GAPDH in each sample.

and GPx protein levels were also higher in the envenomated group. These results were supported by the activities of the corresponding enzymes (Table 3).

Figure 2 shows alterations in the activity of mitochondrial respiratory complexes. Complex II, III, III and V activities in the examined livers of envenomated rats were decreased by $56 \%, 5 \%, 12 \%$ and $26 \%$, respectively, $p<0.05$ when compared to the controls.

Effects of $N$. haje crude venom on Bax and Bcl-2 protein content in the liver are presented in Figure 2. $N$. haje venom injection caused a significant $(p<0.05)$ increase in Bax and a significant decrease in $\mathrm{Bcl}-2$ protein content $(p<0.05)$.

Hepatocytes were stained with both propodium iodide (PI) and fluorescein isothiocyanate (FITC)-labeled annexin $\mathrm{V}$ (AV-FITC) in order to enable the analysis of apoptotic cells with flow cytometry. Necrotic cells were demonstrated by $\mathrm{AV}-/ \mathrm{PI}+$ or $\mathrm{AV}+/ \mathrm{PI}+$ staining, because when membrane integrity is lost PI enters cells and combines with nucleic acids. Early apoptotic cells were demonstrated by $\mathrm{AV}+/ \mathrm{PI}-$ staining, because when AV combines with phosphatidylserine, they translocate to the outer

Table 3 Changes in antioxidant state of rats induced by Naja haje snake venom after four hours

\begin{tabular}{lcc}
\hline Parameters & Control rats & Intoxicated rats \\
\hline Serum GSH (mmol/mL) & $1.56 \pm 0.34$ & $1.01 \pm 0.15^{*}$ \\
Liver GSH (mmol/g tissue) & $92.42 \pm 17.07$ & $56.69 \pm 2.46^{*}$ \\
Liver GPx (U/g tissue) & $1722.43 \pm 69.54$ & $2253.41 \pm 71.24^{*}$ \\
Liver GR ( $\mu \mathrm{mol} / \mathrm{h} / \mathrm{g}$ tissue) & $93.78 \pm 10.75$ & $55.59 \pm 18.27^{*}$ \\
Liver GST ( $\mu \mathrm{mol} / \mathrm{h} / \mathrm{g}$ tissue) & $0.61 \pm 0.02$ & $0.24 \pm 0.01^{*}$ \\
Liver SOD $(\mathrm{U} / \mathrm{g}$ tissue) & $1.06 \pm 0.03$ & $1.72 \pm 0.08^{*}$ \\
Liver CAT (U/g tissue) & $0.41 \pm 0.02$ & $0.13 \pm 0.01^{*}$
\end{tabular}

*significant change at $p<0.05$ with respect to the control group; values are means $\pm S E(n=6)$.

GSH: glutathione, GPx: glutathione peroxidase, GR: glutathione reductase, SOD: superoxide dismutase, CAT: catalase. leaflet of the plasma membrane during apoptosis. AV+/PI + stained cells were likely to be late apoptotic or necrotic cells whereas AV-/PI- cells represented viable cells. In the control group, most liver cells were viable (Figure 3). When rats were exposed to $N$. haje venom, the number of $\mathrm{AV}+$ cells were significantly increased $(67.5 \%, p<0.05)$.

Liver section of control animals (Figure 4A) revealed with normal cell structure, while liver sections of rats injected with $\mathrm{LD}_{50}$ of $N$. haje crude venom showed inflammatory cell infiltration around the hepatic vein, distended blood sinusoids, hepatocyte vacuolation and prominent van Kupffer cells (Figure 4B). Severe necrosis and apoptosis were also seen (Figure 4D). Figure 4E shows severe congestion in the central vein. Immunohistochemical investigations for caspase-3 in hepatocytes of the control and envenomated groups are represented in Figure $4 \mathrm{C}$ and $\mathrm{F}$. In the envenomated group, the number of caspase-3 positive immunostaining hepatocytes was significantly increased, which proves the proapoptotic activity of $N$. haje crude venom (Figure 4F).

\section{Discussion}

Several studies analyzing snake venom effects on animal cells - from blood, marrow, muscle, liver, kidney and skin - showed different results, depending on the experimental concentrations, exposure time, site of injection, and the type of toxin [31,32]. The liver is a major producer of most serum proteins and their total levels in the blood are regulated by the liver function. In the present study, the elevation of ALT, AST, yGT, ALP, and total bilirubin in envenomated rats could be attributed to the hepatocyte damage. Such imbalance has been reported by other researchers who analyzed snake venom effects [33-35].

The mechanism by which $N$. haje venom induces cytotoxic effects is still not clear. To the best of our knowledge, there are no available data regarding the involvement of oxidative stress induced by $N$. haje venom exposure in vitro. In order to evaluate the ability of $N$. haje venom to produce oxidative stress, we choose to monitor one of the earliest responses of oxidative stress, which is the increase of stress markers in liver homogenates.

Levels of early markers of oxidative stress, including antioxidant enzymes, may be altered in the presence of lower levels of oxidative stress. To this end, we have monitored antioxidant enzyme activities. Our results clearly showed that $N$. haje venom enhances SOD and GPx activities (Table 3). The induction of the enzymatic antioxidant defenses after the exposure to $N$. haje venom could be considered as an adaptive response; that is, a compensatory mechanism that enables cells to overcome the damage caused.

To further demonstrate the implication of oxidative stress in venom induced toxicity, we decided to monitor 


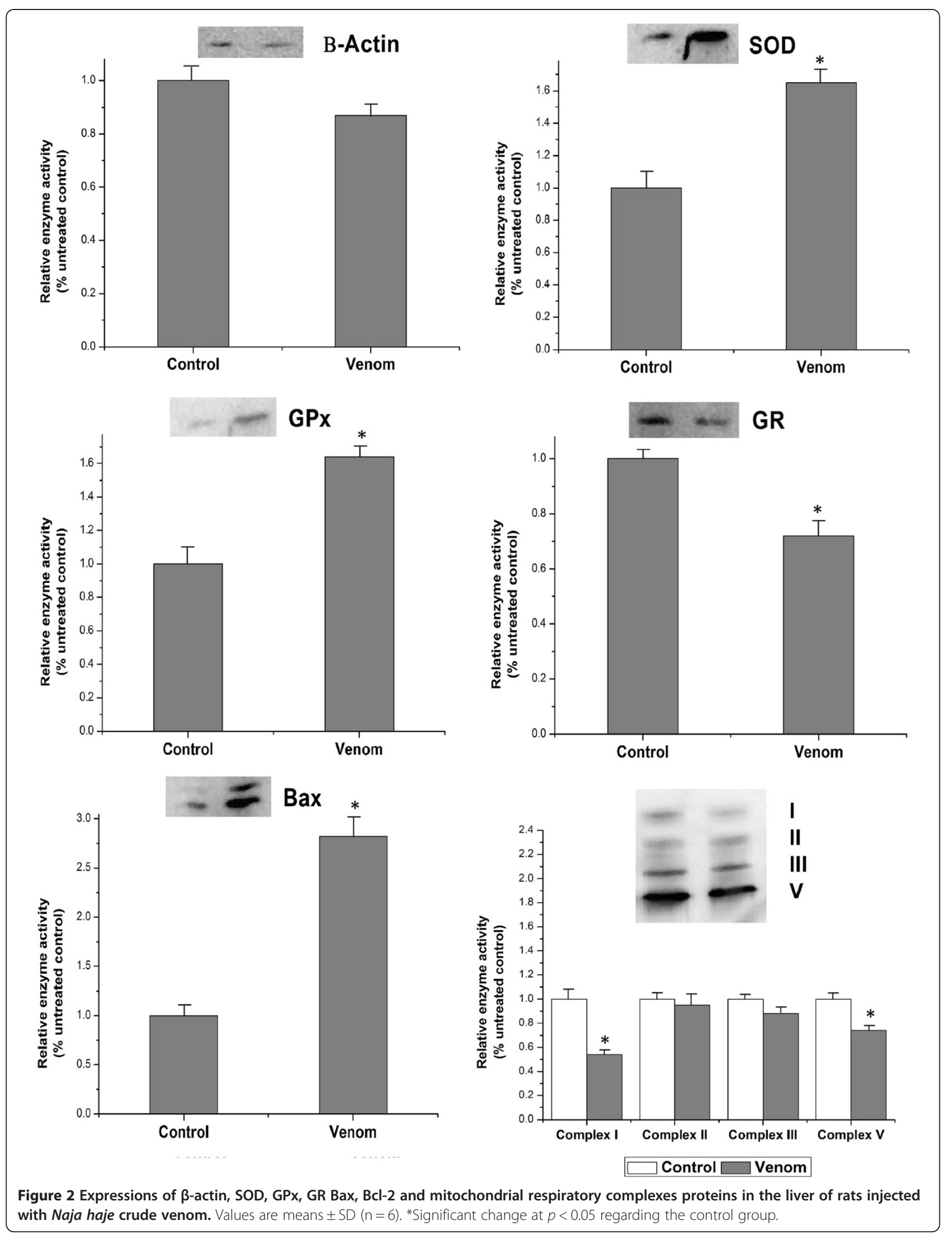



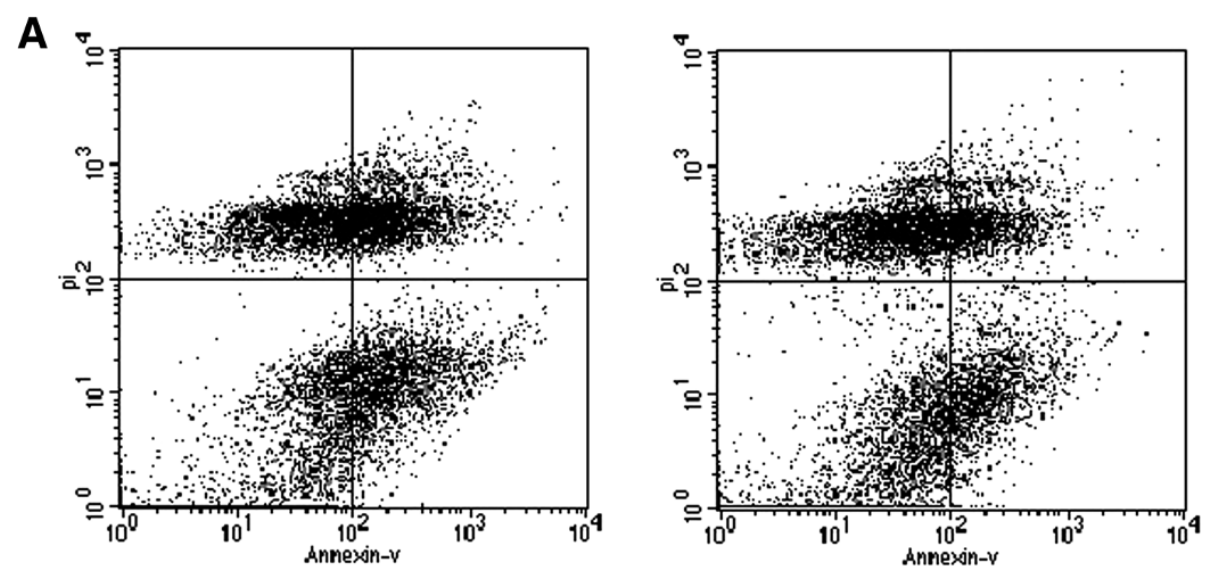

B

\begin{tabular}{|l|c|c|c|}
\cline { 2 - 4 } \multicolumn{1}{c|}{} & Viable cells & $\begin{array}{c}\text { Early apoptotic } \\
\text { cells }\end{array}$ & $\begin{array}{c}\text { Late apoptotic } \\
\text { and necrotic } \\
\text { cells }\end{array}$ \\
\hline Intoxicated liver & $26.3 \%$ & $32.5 \%$ & $35.0 \%$ \\
\hline
\end{tabular}

Figure 3 Assessment of apoptosis in hepatic tissue of male rats injected with Naja haje crude venom. (A) Representative flow cytometry dot plot of FITC-annexin V/propidium iodide. (B) Table showing: viable cells, early apoptotic cells, and late apoptotic and necrotic cells.

LPO. Lipid peroxidation is one of the suggested cytotoxic mechanisms of different venoms. The MDA is an end product of lipid peroxidation, considered as a late biomarker of oxidative stress and cellular damage [36]. It is generally considered as an excellent indicator of lipid peroxidation [37]. We have shown an increase of lipid peroxidation level that seemed related to $N$. haje crude venom as inferred by the amount of MDA generated, confirming an increase of free radicals production. This fact emphasizes that the oxidative damage is induced by the venom in the liver of rats (Table 2).
In addition, venom phospholipase caused a disturbance of the cell membrane permeability with consequent influx of $\mathrm{Na}^{+}$and water [38]. Chethankumar and Srinivas [39] concluded that the exposure of cellular membranes to $N$. haje venom phospholipase significantly decreased the $\mathrm{Na}^{+} / \mathrm{K}^{+}$ATPase activities, thereby altering the ionic gradients, disorganizing the membrane lipid bilayer and eventually leading to cell death. According to Mukherjee and Maity [40], the progression of hepatic cellular swelling together with the effect of the venom phospholipase on the membranous phospholipids during

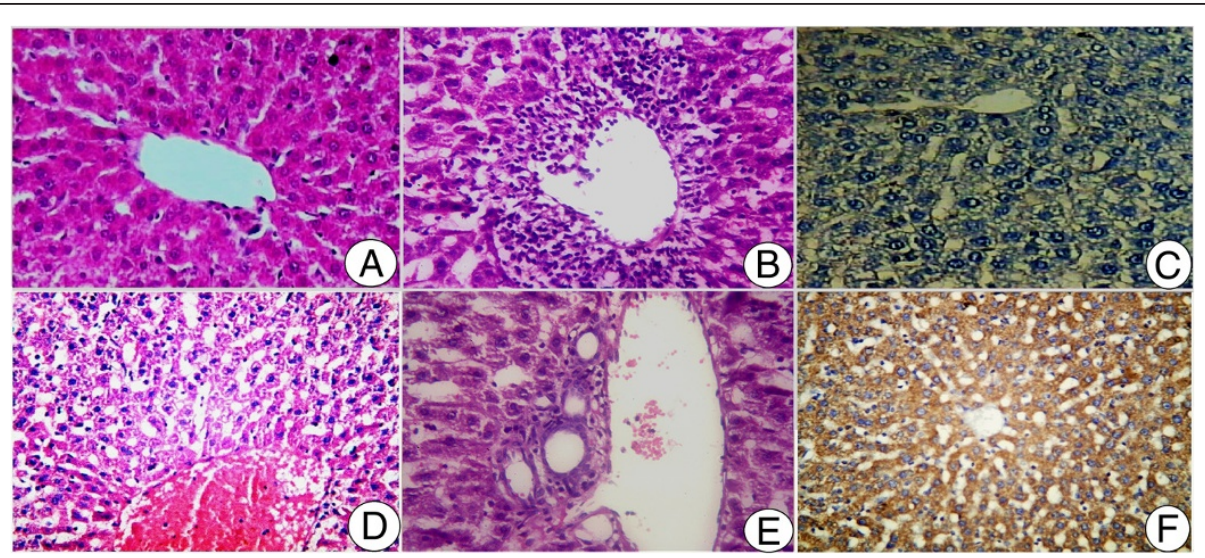

Figure 4 Histological and immunohistochemical investigations in the livers of rats. (A) Control liver section. (B, D, E) Naja haje group liver sections (HE stain, 400X). (C) Section from control group showing low affinity to caspase-3. (F) Section from the group treated with Naja haje crude venom showing high affinity to caspase-3. 
envenomation might be among the factors responsible for the rupture of hepatic cell membranes and the occurrence of the observed cellular damage in the present study.

L-amino acid oxidases (LAAOs) are flavoproteins that are able to catalyze the oxidative deamination of Lamino acids to produce the corresponding $\alpha$-keto acids along with the concomitant release of hydrogen peroxide $\left(\mathrm{H}_{2} \mathrm{O}_{2}\right)$ and ammonia. Although they occur in many different organisms from invertebrates to vertebrates, their functions in vivo are uncertain. LAAO is widely distributed in venomous snakes including the viperids and elapids and is thought to contribute to their toxicity, possibly through $\mathrm{H}_{2} \mathrm{O}_{2}$ formed as a result of reoxidation of the transiently reduced FAD cofactor by molecular oxygen $[41,42]$. The enzyme is the major component of snake venoms, and in some species this enzyme alone constitutes approximately $30 \%$ of the total protein content [42,43]. Furthermore, venom LAAO has been shown to induce cell death in several mammalian cell lines [44]. The effect was attributed to the formation of localized high concentrations of $\mathrm{H}_{2} \mathrm{O}_{2}$, a known reactive oxygen species (ROS). It is interesting to note that the LAAO-induced apoptosis has been reported to be different from that caused by exogenous $\mathrm{H}_{2} \mathrm{O}_{2}$, suggesting that the mode of delivery of $\mathrm{H}_{2} \mathrm{O}_{2}$ is an important factor. In addition, snake venom LAAOs appear to be cytotoxic against many organisms [45].

Tempone et al. [46] suggested that cells submitted to oxidative stress induced by LAAO generated $\mathrm{H}_{2} \mathrm{O}_{2}$ that could activate heat shock proteins and initiate cell membrane disorganization, DNA fragmentation, apoptosis and therefore cell death. Sun et al. [47] suggested that the generated peroxide activates the transcription of such factors as the nuclear factor $\mathrm{B}$, the activator protein 1, Fas/Apo-1 and p53.

Apoptosis is an extremely complex and sophisticated process, involving many events, including the expression of apoptosis-related genes. In general, apoptosis is a three-stage process that includes initiation, effector and degradation periods. The initiation phase is largely dependent on cell type and apoptotic stimulus (e.g., oxidative stress, DNA damage, etc.). During the initiation phase, specific pro-apoptotic signal transduction pathways or non-specific damage pathways are activated. In certain instances, initiation phase may influence the efficacy of the effector and/or degradation phases. In the effector phase, there is activation of proteases, nucleases, and other diffusible intermediaries that participate in the degradation phase of DNA. Together, the effector and degradation phases promote the ultrastructural features that are suggestive of apoptosis. Finally, these steps are followed by rapid engulfment of the deceased cell by neighboring phagocytic cells [48].
Internal and external mitochondrial membrane permeability (MMP) changes led to disappearance of MMP and release of cytochrome $\mathrm{c}$ and other pro-apoptotic factors into the cytosol. The release of pro-apoptotic factors in the cytoplasm may initiate apoptosis cascade reaction, which includes activation of caspase- 3 and other substances that trigger proteolytic enzymes and break DNA into fragments [49]. Our data revealed that $N$. haje snake venom induces apoptosis in hepatocytes through increased transcription of caspase- 3 gene. These results suggest that $N$. haje venom components may increase expression of certain pro-apoptotic genes that lead to cell apoptosis.

\section{Conclusion}

In conclusion, despite advances in our understanding of the hepatotoxicity response to $N$. haje venom, much remains to be learned on the mechanisms involved in the initiation and development of the hepatotoxicity events triggered by this venom. Particularly regarding the range of mediators involved, the regulatory steps associated with their production and action, and the actual types and subtypes of receptors activated by the main mediators. A deficit in our study is the usage of crude venom, therefore it is difficult to establish which component lead to our results.

\section{Abbreviations}

CAT: Catalase; GPx: Glutathione peroxidase; GR: Glutathione reductase; GSH: Glutathione; GST: Glutathione-S-transferase; LPO: Lipid peroxidation; MDA: Malondialdehyde; NO: Nitric oxide; ROS: Reactive oxygen species; SOD: Superoxide dismutase.

\section{Competing interests}

The authors declare that there are no competing interests.

\section{Authors' contributions}

All authors have read and approved the final manuscript.

\section{Acknowledgments}

The authors would like to extend their sincere appreciation to the Deanship of Scientific Research at king Saud University for its funding this Research group NO (RG -1435-002).

\section{Author details}

'Department of Zoology, College of Science, King Saud University, Riyadh, Saudi Arabia. ${ }^{2}$ Department of Zoology and Entomology, Faculty of Science, Helwan University, Cairo, Egypt. ${ }^{3}$ Department of Biochemistry and Molecular Biology, Asturias Institute of Biotechnology, University of Oviedo, 33006 Oviedo, Spain.

Received: 6 June 2014 Accepted: 11 September 2014

Published: 15 September 2014

\section{References}

1. Yamazaki Y, Morita T: Snake venom components affecting blood coagulation and the vascular system: structural similarities and marked diversity. Curr Pharm Des 2007, 13(28):2872-2886.

2. O'Shea M: Venomous Snakes of the World. London: New Holland; 2005.

3. Spawls S, Branch B: The Dangerous Snakes of Africa: Natural History, Species Directory, Venoms and Snakebite. London: Blandford; 1995 
4. Tohamy AA, Mohamed AF, Abdel Moneim AE, Diab MSM: Biological effects of Naja haje crude venom on the hepatic and renal tissues of mice. J King Saud Univ Sci 2014, 26(3):205-212

5. Gutiérrez JM, Ownby CL: Skeletal muscle degeneration induced by venom phospholipases A2: insights into the mechanisms of local and systemic myotoxicity. Toxicon 2003, 42(8):915-931.

6. Gutiérrez JM, Escalante T, Rucavado A: Experimental pathophysiology of systemic alterations induced by Bothrops asper snake venom. Toxicon 2009, 54(7):976-987.

7. Fox JW, Serrano SM: Structural considerations of the snake venom metalloproteinases, key members of the M12 reprolysin family of metalloproteinases. Toxicon 2005, 45(8):969-985.

8. Laing GD, Clissa PB, Theakston RD, Moura-da-Silva AM, Taylor MJ: Inflammatory pathogenesis of snake venom metalloproteinase-induced skin necrosis. Eur J Immunol 2003, 33(12):3458-3463.

9. Teixeira CF, Landucci EC, Antunes E, Chacur M, Cury Y: Inflammatory effects of snake venom myotoxic phospholipases A2. Toxicon 2003 42(8):947-962.

10. Chioato L, Ward RJ: Mapping structural determinants of biological activities in snake venom phospholipases $\mathrm{A} 2$ by sequence analysis and site directed mutagenesis. Toxicon 2003, 42(8):869-883.

11. Montecucco C, Gutiérrez JM, Lomonte B: Cellular pathology induced by snake venom phospholipase A2 myotoxins and neurotoxins: common aspects of their mechanisms of action. Cell Mol Life Sci 2008, 65(18):2897-2912.

12. Gutiérrez JM, Rucavado A, Escalante T, Lomonte B, Angulo Y, Fox JW: Tissue pathology induced by snake venoms: how to understand a complex pattern of alterations from a systems biology perspective? Toxicon 2010, 55(1):166-170.

13. Carroll IM, Andrus JM, Bruno-Barcena JM, Klaenhammer TR, Hassan HM, Threadgill DS: Anti-inflammatory properties of Lactobacillus gasseri expressing manganese superoxide dismutase using the interleukin 10-deficient mouse model of colitis. Am J Physiol Gastrointest Liver Physiol 2007, 293(4):G729-G738

14. Miura N, Yamamoto M, Ueki T, Kitani T, Fukuda K, Komatsu Y: Inhibition of thymocyte apoptosis by berberine. Biochem Pharmacol 1997, 53(9):1315-1322

15. Meier J, Theakston RD: Approximate LD50 determinations of snake venoms using eight to ten experimental animals. Toxicon 1986, 24(4):395-401.

16. Reitman S, Frankel S: A colorimetric method for the determination of serum glutamic oxalacetic and glutamic pyruvic transaminases. Am J Clin Pathol 1957, 28(1):56-63.

17. Szasz G: A kinetic photometric method for serum gamma-glutamyl transpeptidase. Clin Chem 1969, 15(2):124-136.

18. Belfield A, Goldberg DM: Revised assay for serum phenyl phosphatase activity using 4-amino-antipyrine. Enzyme 1971, 12(5):561-573.

19. Schmidt M, Eisenburg J: Serumbilirubin-bestimmung beim neugeborenen. Eine neue mikromethode für die bestimmung des serum-bzw plasmabilirubins beim neugeborenen. Fortschr Med 1975, 93(30):1461-1466.

20. Ohkawa $\mathrm{H}$, Ohishi $\mathrm{N}$, Yagi K: Assay for lipid peroxides in animal tissues by thiobarbituric acid reaction. Anal Biochem 1979, 95(2):351-358.

21. Green LC, Wagner DA, Glogowski J, Skipper PL, Wishnok JS, Tannenbaum SR: Analysis of nitrate, nitrite, and [15N]nitrate in biological fluids. Anal Biochem 1982, 126(1):131-138.

22. Ellman GL: Tissue sulfhydryl groups. Arch Biochem Biophys 1959, 82(1):70-77.

23. Aebi H: Catalase in vitro. Methods Enzymol 1984, 105:121-126.

24. Nishikimi M, Appaji N, Yagi K: The occurrence of superoxide anion in the reaction of reduced phenazine methosulfate and molecular oxygen. Biochem Biophys Res Commun 1972, 46(2):849-854

25. Habig WH, Pabst MJ, Jakoby WB: Glutathione S-transferases. The first enzymatic step in mercapturic acid formation. J Biol Chem 1974 249(22):7130-7139.

26. Paglia DE, Valentine WN: Studies on the quantitative and qualitative characterization of erythrocyte glutathione peroxidase. J Lab Clin Med 1967, 70(1):158-169.

27. Factor VM, Kiss A, Woitach JT, Wirth PJ, Thorgeirsson SS: Disruption of redox homeostasis in the transforming growth factor-alpha/c-myc transgenic mouse model of accelerated hepatocarcinogenesis. J Biol Chem 1998, 273(25):15846-15853.
28. Chomczynski P, Sacchi N: Single-step method of RNA isolation by acid guanidinium thiocyanate-phenol-chloroform extraction. Anal Biochem 1987, 162(1):156-159.

29. Carleton HM, Drury RAB, Wallington EA: Chapter 7, General staining procedures. In Carleton's Histological Technique, Series: Oxford Medical Publications. 5th edition. Edited by Wallington EA. New York: Oxford University Press; 1980:147-148.

30. Pedrycz A, Czerny K: Immunohistochemical study of proteins linked to apoptosis in rat fetal kidney cells following prepregnancy adriamycin administration in the mother. Acta Histochem 2008, 110(6):519-523

31. Maria DA, Vassão RC, Ruiz IR: Haematopoietic effects induced in mice by the snake venom toxin jararhagin. Toxicon 2003, 42(6):579-585.

32. Fox JW, Serrano SM: Exploring snake venom proteomes: multifaceted analyses for complex toxin mixtures. Proteomics 2008, 8(4):909-920.

33. Barraviera B, Bonjorno Junior JC, Arkaki D, Domingues MA, Pereira PC, Mendes RP, Machado JM, Meira DA: A retrospective study of 40 victims of Crotalus snake bites. Analisys of the hepatic necrosis observed in one patient. Rev Soc Bras Med Trop 1989, 22(1):5-12.

34. Barraviera B, Coelho KYR, Curi PR, Meira DA: Liver dysfunction in patients bitten by Crotalus durissus terrificus (Laurenti, 1768) snakes in Botucatu (State of São Paulo, Brazil). Rev Inst Med Trop Sao Paulo 1995, 37(1):63-69.

35. França RF, Vieira RP, Ferrari EF, Souza RA, Osorio RAL, Prianti-jr ACG, Hyslop S, Zamuner SR, Cogo JC, Ribeiro W: Acute hepatotoxicity of Crotalus durissus terrificus (South American rattlesnake) venom in rats. J Venomous Anim Toxins Ind Trop Dis 2009, 15(1):61-78. http://www.scielo.br/scielo.php?pid=S1678-91992009000100007\& script=sci_arttext.

36. Ayed Y, Boussabbeh M, Zakhama W, Bouaziz C, Abid S, Bacha H: Induction of cytotoxicity of Pelagia noctiluca venom causes reactive oxygen species generation, lipid peroxydation induction and DNA damage in human colon cancer cells. Lipids Health Dis 2011, 10:232. doi:10.1186/1476-511X-10-232

37. Othman MS, Safwat G, Aboulkhair M, Abdel Moneim AE: The potential effect of berberine in mercury-induced hepatorenal toxicity in albino rats. Food Chem Toxicol 2014, 69:175-181.

38. Segelke BW, Nguyen D, Chee $R$, Xuong NH, Dennis EA: Structures of two novel crystal forms of Naja naja naja phospholipase A2 lacking Ca2+ reveal trimeric packing. J Mol Biol 1998, 279(1):223-232.

39. Chethankumar M, Srinivas L: Gangliosides as potential inhibitors of Naja naja venom $\mathrm{PLA} \mathrm{A}_{2}\left(\mathrm{NV}-\mathrm{PLA} \mathrm{A}_{2}\right)$ induced human erythrocyte membrane damage. Afr J Biochem Res 2008, 2(1):8-14.

40. Mukherjee AK, Maity CR: The composition of Naja naja venom samples from three districts of West Bengal, India. Comp Biochem Physiol A Mol Integr Physiol 1998, 119(2):621-627.

41. MacHeroux $P$, Seth $O$, Bollschweiler C, Schwarz M, Kurfürst M, Au LC, Ghisla S: L-amino-acid oxidase from the Malayan pit viper Calloselasma rhodostoma. Comparative sequence analysis and characterization of active and inactive forms of the enzyme. Eur J Biochem 2001, 268(6):1679-1686

42. Costa TR, Burin SM, Menaldo DL, Castro FA, Sampaio SV: Snake venom L-amino acid oxidases: an overview on their antitumor effects. J Venomous Anim Toxins Ind Trop Dis 2014, 20(23):]. doi:10.1186/1678-9199-2023. [http://www.scielo.br/scielo.php?.pid=\$1678-91992014000100206\&script= sci_arttext]

43. Du XY, Clemetson KJ: Snake venom L-amino acid oxidases. Toxicon 2002 40(6):659-665.

44. Ande SR, Kommoju PR, Draxl S, Murkovic M, Macheroux P, Ghisla S, Ferrando-May E: Mechanisms of cell death induction by L-amino acid oxidase, a major component of ophidian venom. Apoptosis 2006, 11(8):1439-1451.

45. Naumann GB, Silva LF, Silva L, Faria G, Richardson M, Evangelista K, Kohlhoff M, Gontijo CM, Navdaev A, de Rezende FF, Eble JA, Sanchez EF: Cytotoxicity and inhibition of platelet aggregation caused by an L-amino acid oxidase from Bothrops leucurus venom. Biochim Biophys Acta 2011, 1810(7):683-694

46. Tempone AG, Andrade HF Jr, Spencer PJ, Lourenço CO, Rogero JR, Nascimento $\mathrm{N}$ : Bothrops moojeni venom kills Leishmania spp. with hydrogen peroxide generated by its L-amino acid oxidase. Biochem Biophys Res Commun 2001, 280(3):620-624. 
47. Sun LK, Yoshii Y, Hyodo A, Tsurushima H, Saito A, Harakuni T, Li YP, Kariya K, Nozaki M, Morine N: Apoptotic effect in the glioma cells induced by specific protein extracted from Okinawa Habu (Trimeresurus flavoviridis) venom in relation to oxidative stress. Toxicol Vitro 2003, 17(2):169-177.

48. Marzo I, Brenner C, Zamzami N, Susin SA, Beutner G, Brdiczka D, Rémy R Xie ZH, Reed JC, Kroemer G: The permeability transition pore complex: a target for apoptosis regulation by caspases and bcl-2-related proteins. J Exp Med 1998, 187(8):1261-1271.

49. Abdel Moneim AE: Prevention of carbon tetrachloride (CCI4)-induced toxicity in testes of rats treated with Physalis peruviana L. fruit. Toxicol Ind Health. in press. doi:10.1177/0748233714545502.

doi:10.1186/1678-9199-20-42

Cite this article as: Al-Quraishy et al:: Hepatotoxicity and oxidative stress induced by Naja haje crude venom. Journal of Venomous Animals and Toxins including Tropical Diseases 2014 20:42.

\section{Submit your next manuscript to BioMed Central and take full advantage of:}

- Convenient online submission

- Thorough peer review

- No space constraints or color figure charges

- Immediate publication on acceptance

- Inclusion in PubMed, CAS, Scopus and Google Scholar

- Research which is freely available for redistribution 